\title{
Long-term morphological and immunohistochemical observations on biopsy specimens of small intestine from children with gluten-sensitive enteropathy
}

\author{
PCM ROSEKRANS,* CJLM MEIJER, $†$ I POLANCO $\ddagger$ ML MEARIN,* \\ AM VAN DER WAL, $\dagger$ AND J LINDEMAN $\dagger$
}

From the *Department of Gastroenterology and $\dagger$ Department of Pathology, University Medical Centre, Leiden, The Netherlands, and $\ddagger$ Gastroenterologic Unit of the Paediatric Clinic, University Hospital La Paz, Madrid, Spain

SUMMARY Jejunal biopsy specimens from nine Spanish children with gluten-sensitive enteropathy were studied with morphometric and immunohistochemical techniques in three stages of the disease: the first biopsy was taken for diagnosis, when the child had a gluten-containing diet, the second after gluten withdrawal, and the third biopsy after gluten-provocation. The findings were compared with those in 10 healthy adults. The villous:crypt ratio and the length of the surface epithelium perstretched millimetre muscularis mucosae were decreased, whereas the number of interepithelial lymphocytes per millimetre surface epithelium was increased when the child had a gluten-containing diet. Although these parameters improved after withdrawal of gluten for at least seven months, they never reached the values of the healthy control group.

With the indirect immunoperoxidase technique it was shown that the numbers of IgA-, IgG-, and IgM-containing cells, expressed per 'mucosal tissue unit' of $4 \mu \mathrm{m}$ thick and $1 \mathrm{~mm}$ wide, were sig-을 nificantly increased during the active phases of the disease. This increase was most striking for the IgM-containing cells.

The most sensitive parameters for the histological diagnosis of gluten-sensitive enteropathy are the villous:crypt ratio or the length of the surface epithelium per millimetre muscularis mucosae, $:$ the number of interepithelial lymphocytes per millimetre surface epithelium, and the number of 3 . IgM-containing cells per millimetre muscularis mucosae.

For the diagnosis of gluten-sensitive enteropathy (GSE) certain essential morphological features must be recognised in small intestinal biopsies. The first requirement is the demonstration of an abnormal mucosa, usually flat, while the patient is on a gluten-containing diet; second is the demonstration of a clear improvement of villous structure on a gluten-free diet; and third is the return of an abnormal mucosa when the child is challenged by a gluten-containing diet. In some children with GSE it may take up to at least two years, and occasionally longer, before the mucosa again shows villous atrophy after a return to a gluten-containing diet. ${ }^{1}$

Accepted for publication 27 August 1980
The number of interepithelial lymphocytes is increased during the active phase of the disease and을. decreases when patients are put on a gluten-free diet, $\overline{\mathrm{N}}$ though the numbers do not return to normal. ${ }^{2-4}$ In ? GSE, with the exception of the earlier reports, ${ }^{5-6} \mathrm{~N}$ IgM-containing cells in the lamina propria have $N$ been found to increase. ${ }^{7-10}$ In children, IgG-con- $\sigma$ taining cells are also increased.11-13 The total number of immunoglobulin-containing cells falls on $\frac{\bar{\Phi}}{\varnothing}$ withdrawal of gluten. The potential for response on a $\stackrel{+}{+}$ gluten-free diet appears to be better in children. In 0 the present study the morphological and immuno- ${ }^{\circ}$ histochemical findings in sequential jejunal biopsy $\stackrel{\mathbb{Q}}{\mathbb{Q}}$ specimens from nine Spanish children with GSE are $\mathbb{\mathbb { D }}$ compared with those of a healthy control group. 


\section{Patients}

We studied proximal jejunal biopsy specimens from nine Spanish children with the typical clinical and histological characteristics of GSE. The small intestine biopsy specimens were taken $(a)$ when the child was on a gluten-containing diet for diagnosis, (b) after withdrawal of gluten, for at least seven months, and (c) after gluten-provocation, at least one month after reintroduction of gluten to the diet.

The clinical data of these children are shown in Table 1.

All patients improved on the gluten-free diet and were free of complaints at the time of the second biopsy. Only two patients (cases 3 and 9) had symptoms after reintroduction of gluten to the diet. One child (case 5) had no signs or symptoms of malabsorption. All the other children had increased fat excretion in the stools. The child who had no malabsorption after six months' gluten-provocation did not develop villous atrophy in this period. His mother and two of his brothers have GSE.

The control group consisted of 10 adults as we considered it unethical to perform intestinal biopsies in healthy children. These subjects had a jejunal biopsy done as a healthy volunteer or as a healthy family member of a GSE patient in connection with a family study. 14

\section{Methods}

Peroral biopsies of the proximal jejunal mucosa were performed under radiological control using a hydraulic multiple biopsy capsule. The biopsy specimens were taken to the ligament of Treitz. Under a dissecting microscope the biopsy specimen was orientated, with a minimum of handling, on a mesh to which it adhered. After fixation in Bouin's solution for 3 hours the tissue samples were embedded in paraplast. Tissue sections were cut $4 \mu \mathrm{m}$ thick, perpendicular to the luminal surface, and mounted on glass slides. Sections were stained with haematoxylin and eosin (HE) and specifically for IgA, IgG, IgM, and IgE heavy chains using indirect immunoperoxidase techniques as described earlier. ${ }^{15}$ The specificity of the antisera and control staining procedures have already been reported. ${ }^{15}$

The stained slides were used for morphometric study. Images of the HE and immunoperoxidase stained sections were projected with a standard magnification of $\times 200$ on graph paper, and drawings were made. Morphometric analysis of the drawn figures was carried out on a graphic tablet (Tektronix) interfaced to a small laboratory computer (PDP 11-10, Digital Equipment Corp, Maynard, USA).

The following parameters were measured (Fig. 1): mean villous:crypt ratio, that is, the linear

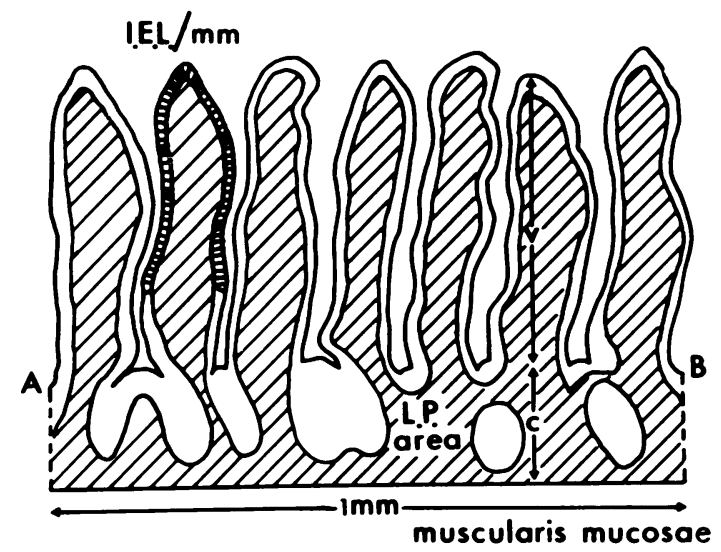

Fig. 1 Morphometry of jejunal biopsies: $v / c=$ villous: crypt ratio; IEL = number of interepithelial cells per mm surface epithelium; $A B=$ length of surface epithelium per $\mathrm{mm}$ stretched muscularis mucosae; $L P$ area = lamina propria cross-sectional area per $\mathrm{mm}$ stretched muscularis mucosae.

Table 1 Clinical data for nine children with gluten-sensitive enteropathy

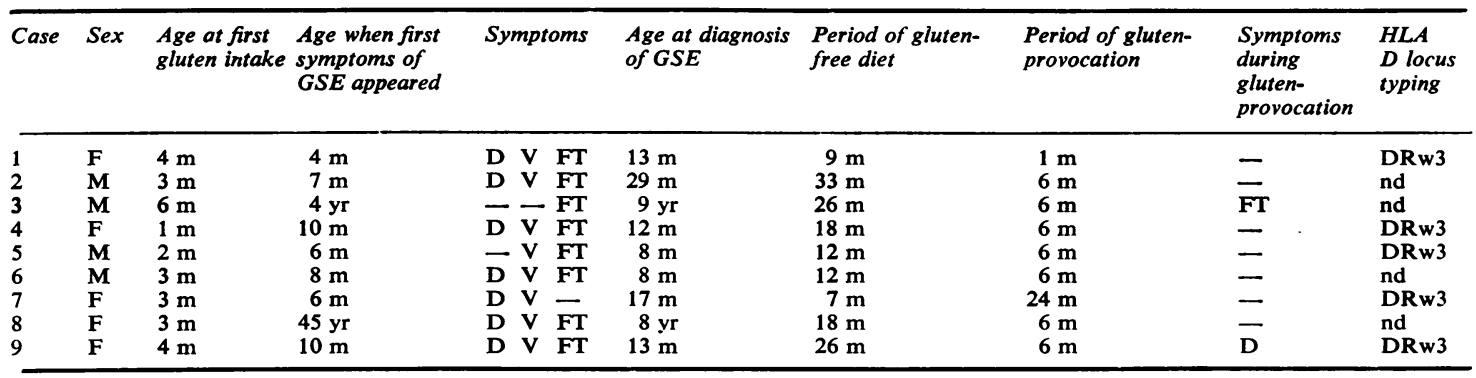

$\mathrm{D}=$ diarrhoea $\mathbf{V}=$ vomiting; $\mathbf{F T}=$ failure to thrive.

nd $=$ not done. 
measurement of five villous heights, divided by the corresponding crypt depths $(\mathrm{V} / \mathrm{C})$;

length of surface epithelium per millimetre stretched muscularis mucosae (SA);

number of interepithelial lymphocytes per millimetre surface epithelium (IEL); and

lamina propria cross-sectional area per millimetre stretched muscularis mucosae (LP area).

The linear measurements of the villous height were made from the top of the villous to the 'mouth' of the crypt of Lieberkühn. The crypt depth was measured as the distance between the 'mouth' of the crypt of Lieberkühn to the upper border of muscularis mucosae. ${ }^{16}$

The slides stained for IgA, IgG, IgM, and IgE were used for counting the immunoglobulincontaining cells per stretched millimetre muscularis mucosae in three consecutive sections. This is comparable to a 'mucosal tissue unit' of $1 \mathrm{~mm}$ width and a thickness of $4 \mu \mathrm{m} .{ }^{17}$

Statistical analysis was performed using Student's $t$ test, and in subsequent observations in one patient Student's $t$ test for paired observations was used. We considered a difference statistically significant when $P<0.01$.

\section{Results}

The first jejunal biopsy (a) showed in all cases total villous atrophy. The villous:crypt ratio was markedly reduced with a corresponding decrease of the length of the surface epithelium per millimetre muscularis mucosae as compared with the healthy controls (Table 2). In the second biopsy (b) these two parameters showed a highly significant increase after withdrawal of gluten (b $v$ a: $\mathbf{P}<0.001$ ). Both improved markedly but the difference compared with the healthy controls was still significant (b $v$ controls: $\mathbf{P}<0.001$ ). Biopsies after glutenprovocation (c) showed for paired observations a significant decrease of villous:crypt ratio and surface epithelium (b $v$ c: $\mathrm{P}<0.001$ ). One patient (case 5) did not develop a villous atrophy after six months' intake of gluten (Figs 2 and 3).

The number of interepithelial lymphocytes per millimetre surface epithelium changed significantly after withdrawal of gluten and gluten-provocation $(P<0.001)$. Although significant improvement was found after withdrawal of gluten the number of interepithelial lymphocytes remained significantly higher than that found in healthy controls $(P<$ 0.001) (Fig. 4).

It is of interest that the lamina propria area per millimetre muscularis mucosae was almost a fixed quantity, and unless the child was growing it did not
Table 2 Morphometric and immunohistochemical results of jejunal biopsy specimens

\begin{tabular}{|c|c|c|c|c|}
\hline & \multirow{2}{*}{$\begin{array}{l}\text { Healthy } \\
\text { controls }\end{array}$} & \multicolumn{3}{|c|}{$\begin{array}{l}\text { Children with gluten-sensitive } \\
\text { enteropathy* }\end{array}$} \\
\hline & & $\begin{array}{l}a \\
(n=9)\end{array}$ & $\begin{array}{l}b \\
(n=9)\end{array}$ & $\begin{array}{l}c \\
(n=9)\end{array}$ \\
\hline $\mathrm{V}: \mathrm{C}$ & $\begin{array}{l}2 \cdot 88 \\
( \pm 0 \cdot 52)\end{array}$ & $\begin{array}{l}0 \cdot 12 \\
( \pm 0 \cdot 16)\end{array}$ & $\begin{array}{l}1.61 \\
( \pm 0.71)\end{array}$ & $\begin{array}{l}0 \cdot 40 \\
( \pm 0 \cdot 41)\end{array}$ \\
\hline $\mathbf{S A}(\mathrm{mm})$ & $\begin{array}{l}6.07 \\
( \pm 0.58)\end{array}$ & $\begin{array}{l}1 \cdot 17 \\
( \pm 0 \cdot 15)\end{array}$ & $\begin{array}{l}3.59 \\
( \pm 0.54)\end{array}$ & $\begin{array}{l}1 \cdot 73 \\
( \pm 0.92)\end{array}$ \\
\hline IEL & $( \pm 4)$ & $\begin{array}{l}83 \\
( \pm 17)\end{array}$ & $\begin{array}{l}37 \\
( \pm 8)\end{array}$ & $\begin{array}{l}76 \\
( \pm 28)\end{array}$ \\
\hline LP area $\left(\mathrm{mm}^{2}\right)$ & $\begin{array}{l}0.23 \\
( \pm 0.03)\end{array}$ & $\begin{array}{l}0.23 \\
( \pm 0.02)\end{array}$ & $\begin{array}{l}0 \cdot 20 \\
( \pm 0.03)\end{array}$ & $\begin{array}{l}0.22 \\
( \pm 0.02)\end{array}$ \\
\hline IgA & $\begin{array}{l}87 \\
( \pm 19)\end{array}$ & $( \pm 50)$ & $\begin{array}{l}79 \\
( \pm 16)\end{array}$ & $( \pm 34)$ \\
\hline IgG & $\begin{array}{l}14 \\
( \pm 6)\end{array}$ & 24 & $\begin{array}{l}14 \\
( \pm 4)\end{array}$ & $\begin{array}{l}21 \\
( \pm 5)\end{array}$ \\
\hline IgM & 23 & $( \pm 27)$ & 26 & 52 \\
\hline
\end{tabular}

$\mathrm{V}: \mathrm{C}=$ villous :crypt ratio; $\mathbf{S A}=$ length of surface epithelium per $\rightarrow$ millimetre stretched muscularis mucosae; IEL $=$ number of inter- $\rightarrow$ epithelial lymphocytes per millimetre surface epithelium; LP area (D) = lamina propria cross-sectional area per millimetre stretched OO muscularis mucosae; IgA, IgG, and IgM = number of $\operatorname{IgA}-, \operatorname{IgG}_{-}$, and IgM-containing cells per millimetre stretched muscularis mucosae; صِ ( \pm SD).

* $a, b$, and $c=$ three times at which a jejunal biopsy was obtained (see text).

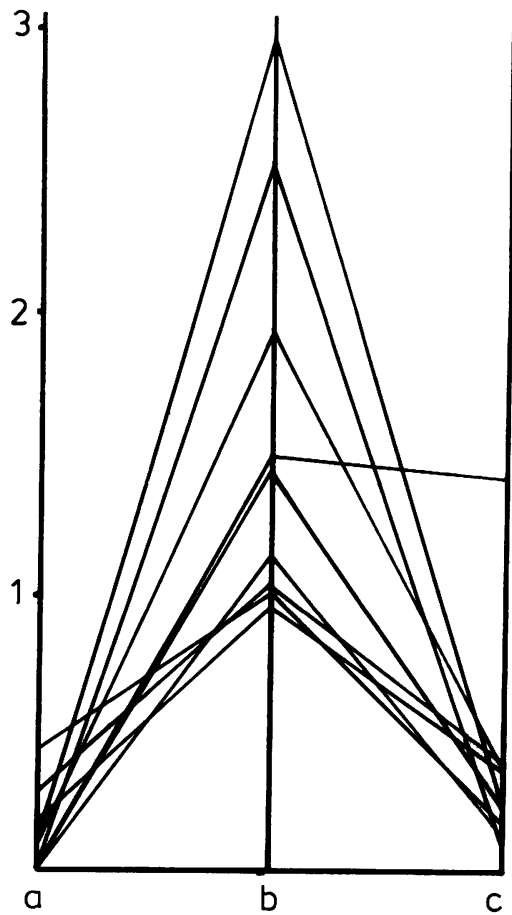

Fig. 2 Villous:crypt ratio in three jejunal biopsy specimens in nine children with GSE: (a) on a glutencontaining diet; (b) after withdrawal of gluten; (c) after gluten-provocation. 


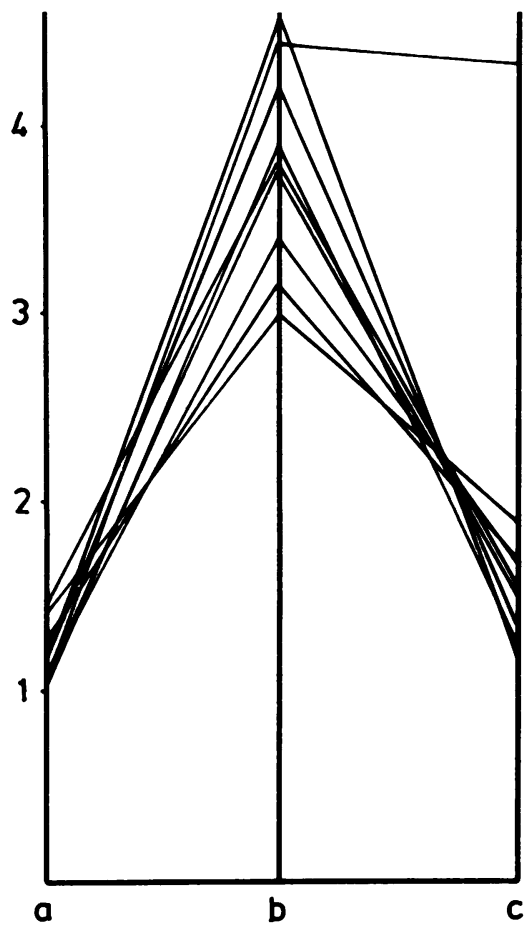

Fig. 3 Length of surface epithelium per $\mathrm{mm}$ muscularis mucosae in three jejunal biopsy specimens in nine children with GSE.

change. There was also no difference compared with the adult control groups.

We compared the numbers of IgA-, IgG-, and IgM-containing cells in the jejunal biopsy specimens of each patient in the sequential biopsies (Figs 5-7). For all three immunoglobulin classes significant changes were found after withdrawal of gluten $(\mathbf{P}<0.01)$. After gluten-provocation significant increases were found in IgG- and IgM-containing cells but no significant change was found in the $\operatorname{IgA}$ containing cells $(P<0.05)$.

A comparison between patients and controls of the numbers of immunoglobulin-containing cells per millimetre muscularis mucosae showed significant differences in the first biopsy (a) for all immunoglobulin-containing cell classes, except IgE. After withdrawal of gluten no significant differences were found. Although IgA-, IgG-, and IgM-containing cells were increased after gluten-provocation, only the number of IgM-containing cells differed significantly $(P<0.001)$ from the controls.

The patient who did not develop villous atrophy after gluten-provocation also showed no changes in the number of immunoglobulin-containing cells. The numbers of IgE-containing cells in the controls and

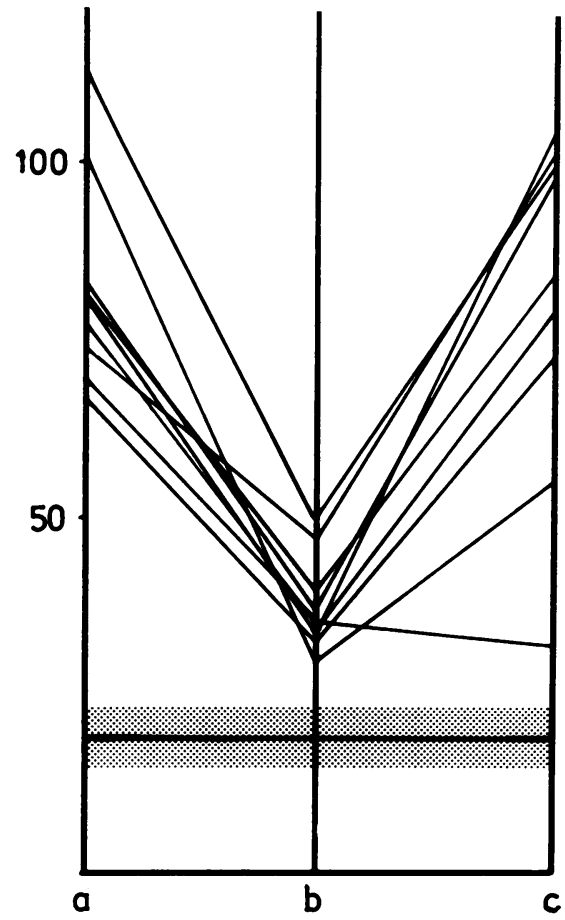

Fig. 4 Number of interepithelial lymphocytes per $\mathrm{mm}$ surface epithelium in three jejunal biopsy specimens in nine children with GSE. Hatched area $=$ mean value of healthy controls $\pm 1 S D$.

in the different stages of GSE were small and showed no consistent increase or decrease.

The follow-up jejunal biopsy findings for IgMcontaining cells in case 7 are shown in Figure 8.

\section{Discussion}

Our study shows that in children with GSE who have been on a gluten-free diet for at least seven months, the jejunal mucosa does not show a complete morphological restitution compared with the healthy control group. The morphometric parametersvillous:crypt ratio, length of surface epithelium per stretched millimetre muscularis mucosae, and number of interepithelial lymphocytes per millimetre surface epithelium after withdrawal of gluten-differ significantly from our findings in the healthy control group.

Most investigators have counted the interepithelial lymphocytes per hundred epithelial cells. ${ }^{2} 3$ 18-21 Holmes et al. ${ }^{22}$ and Ferguson et al. ${ }^{23}$ counted the number of interepithelial lymphocytes per millimetre length of epithelium. Because in active GSE the shape of the epithelial cells is altered and the number per millimetre surface epithelium is de- 


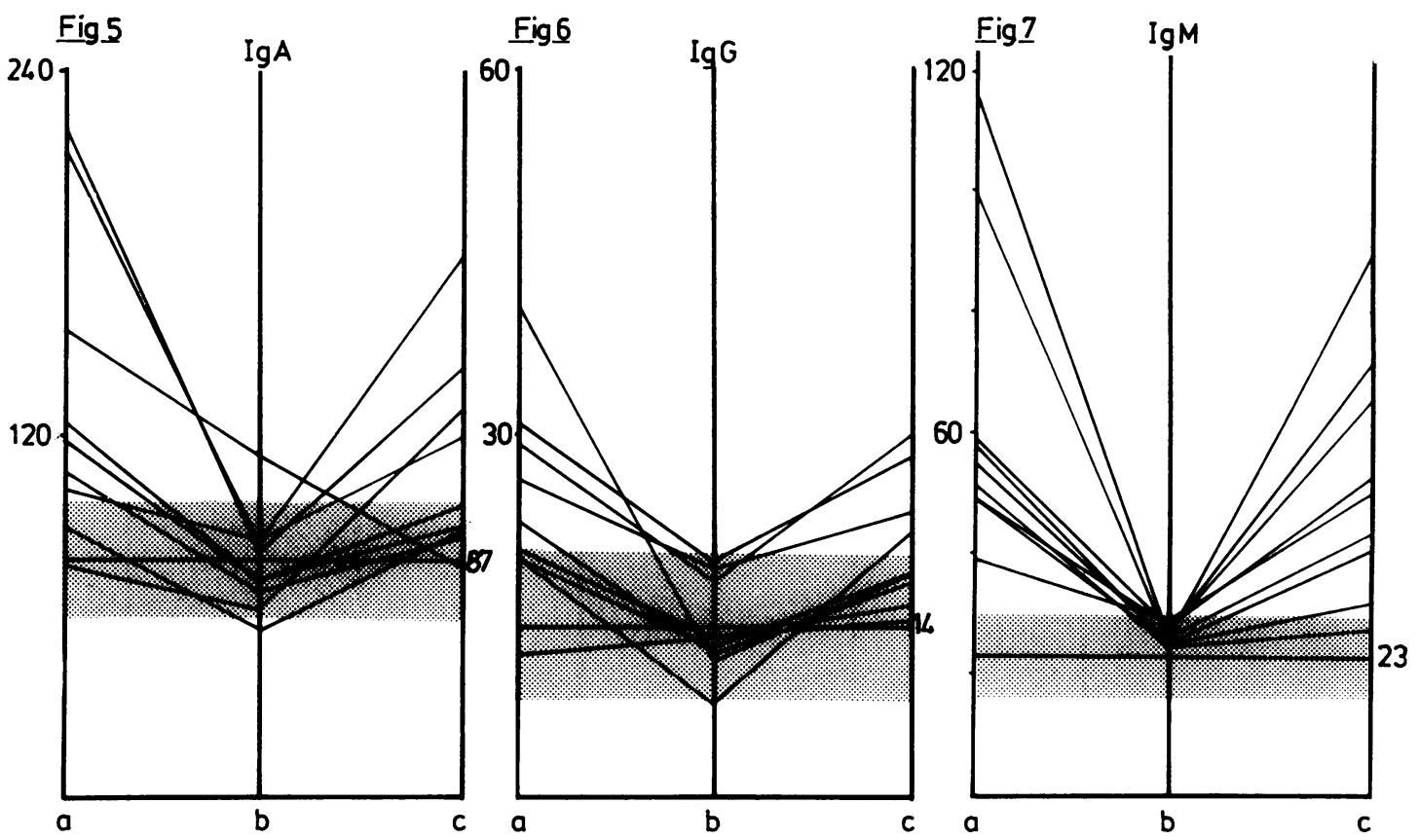

Figs 5, 6, and 7 Numbers of IgA-, IgG-, and IgM-containing cells per mm muscularis mucosae in three jejunal biopsies in nine children with GSE.

creased, we prefer to express the number of interepithelial lymphocytes per millimetre surface epithelium and not per number of epithelial cells. In patients with GSE, we, like others, found a marked increase in the number of interepithelial lymphocytes. After treatment with a gluten-free diet the number of interepithelial lymphocytes decreased, but the value found in healthy controls was never reached. It is interesting that although in GSE the number of interepithelial lymphocytes per millimetre surface epithelium is increased, the total number of interepithelial lymphocytes per millimetre stretched muscularis mucosae (IEL $\times$ SA) is not increased at all in patients with GSE compared with healthy controls (controls: $115 \mathrm{IEL} / \mathrm{mm}$ muscularis mucosae; GSE in active phase: $97 \mathrm{IEL} / \mathrm{mm}$ muscularis mucosae). In children in the active phase of GSE, a pattern of immunoglobulin-containing cells was found with the immunoperoxidase technique in accord with previous accurate observations using immunofluorescence.

The numbers of IgA-, IgG-, and IgM-containing cells in the GSE patients increase significantly in the active phases of the disease, and the most striking quantitative changes were found in the IgMcontaining cells.

These results agree with those of Scott et al.,24 who showed that in children with GSE after gluten- challenge a significant, absolute, and relative increase in the number of IgM-containing cells was found. In addition, they showed that the absolute numbers of IgA- and IgG-containing cells were significantly raised.

From our study it is concluded that the most sensitive parameters for the diagnosis of GSE are: villous:crypt ratio or length of surface epithelium per millimetre muscularis mucosae; number of interepithelial lymphocytes per millimetre surface epithelium; and number of IgM-containing cells per millimetre muscularis mucosae. These quantitative parameters may be used in the interpretation of follow-up biopsies after withdrawal of gluten and reintroduction to confirm the diagnosis histologically. Furthermore, immunohistochemistry of jejunal biopsy specimens is important to distinguish GSE from other causes of villous atrophy, such as immune deficiency and cow's-milk protein intolerance. In this last-mentioned disease, a large number of IgEcontaining cells in the jejunal mucosa is found in contrast to the findings in gluten-sensitive enteropathy. ${ }^{15}$

We gratefully acknowledge help from the many people who made the study possible, including Dr CJ Cornelisse and Mrs A van der Zon for 


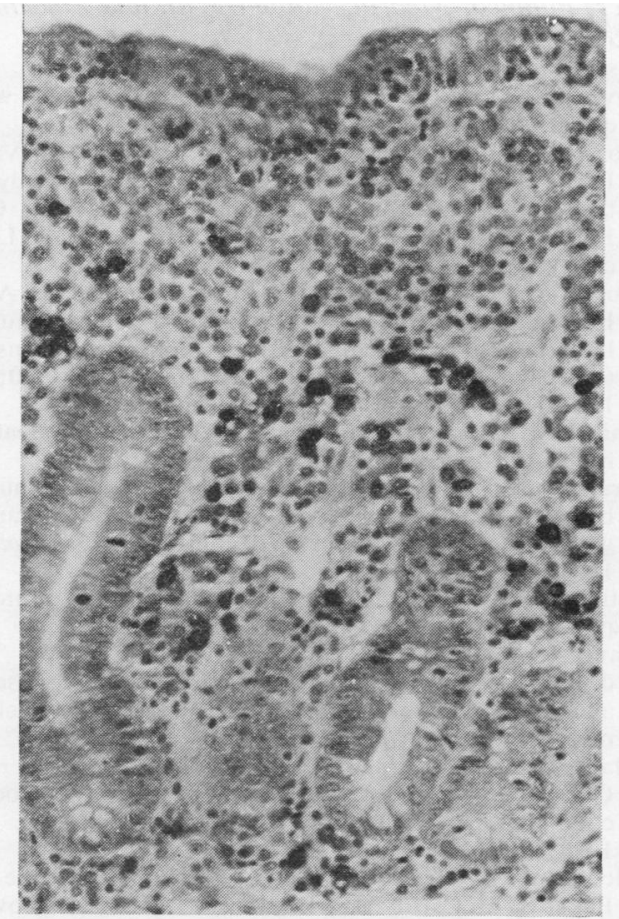

$8 \mathrm{a}$

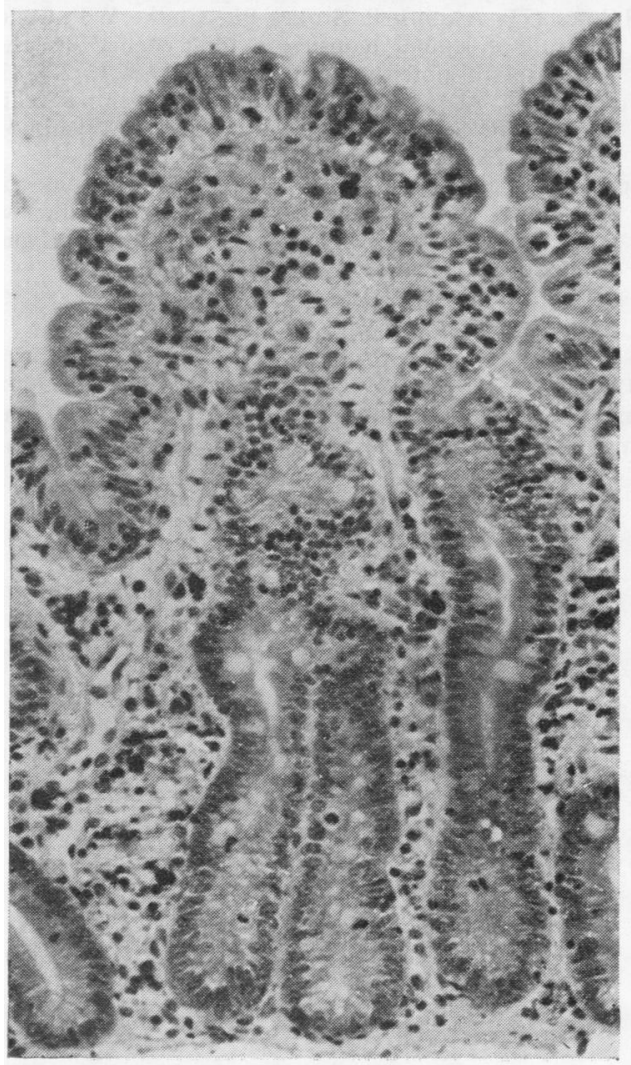

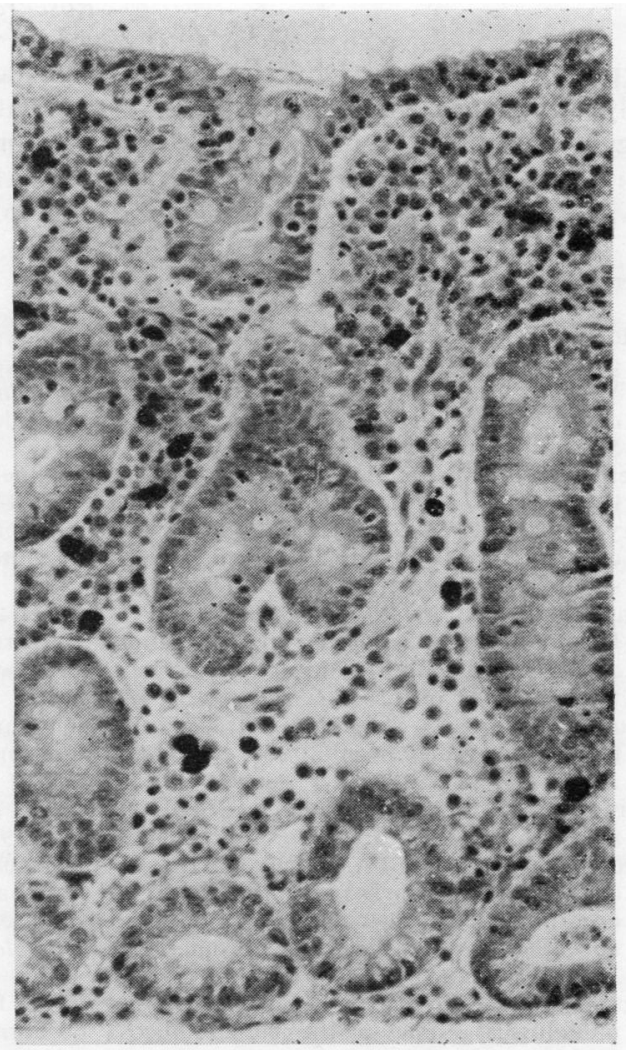

$8 \mathrm{c}$

Fig. 8 Case 7. Three jejunal biopsy specimens stained for IgM using a peroxidase technique: (a) on a glutencontaining diet; (b) seven months after elimination of gluten from the diet; and (c) two years after glutenprovocation. $(\times 80)$ 
morphometric analysis, Dr $\mathbf{J}$ Hermans for statistical analysis, Dr J Larrauri, from the Department of Pathology, University Hospital La Paz, Madrid, for providing the sections of the biopsy specimens, and Mrs $M$ van der Zee-Berkhout for administrative help.

\section{References}

${ }^{1}$ McNicholl B, Egan-Mitchell B, Fottrell PF. Varying gluten susceptibility in coeliac disease. In: Hekkens WThJM, Peña AS, eds. Coeliac disease. Proceedings of the Second International Coeliac Symposium. Leiden: Stenfert Kroese, 1974;413-20.

${ }^{2}$ Ferguson A, Murray D. Quantitation of intraepithelial lymphosytes in human jejunum. Gut 1971;12:988-94.

${ }^{3}$ Fry L, Seam PP, McMinn RMH, Hoffbrand AV. Lymphocytic infiltration of epithelium in diagnosis of glutensensitive enteropathy. $\mathrm{Br} \mathrm{Med} J$ 1972;3:371-4.

${ }^{1}$ Lancaster-Smith M, Packer S, Kumar PJ, Harries JT. Immunological phenomena in the jejunum and serum after reintroduction of dietary gluten in children with treated coeliac disease. J Clin Pathol 1976;29:592-7.

${ }^{5}$ Rubin W, Fauci AS, Sleisenger MH, Jeffries GM. Immunofluorescent studies in adult celiac disease. $J$ Clin Invest $1965 ; 44: 475-85$.

- Crabbé PA. In: Signification du tissu lymphoìde des musques digestives. Bruxelles: Edition Arscia SA, 1967.

${ }^{7}$ Douglas AP, Crabbé PA, Hobbs JR. Immunohistochemical studies of the serum, intestinal secretions and intestinal mucosa in patients with adult coeliac disease and other forms of coeliac syndrome. Gastroenterology 1970;59:414-25.

${ }^{8}$ Gasbarrini G, Miglio F, Serra MA, Berneardi M. Immunological studies of the jejunal 'mucosa in normal subjects and adult celiac patients. Digestion 1974;10: 122-8.

2 Lancaster-Smith M, Packer S, Kumar PJ, Harries JT. Cellular infiltrate of the jejunum after reintroduction of dietary gluten in children with treated coeliac disease. $J$ Clin Pathol 1976;29:587-91.

1" Brandtzaeg P. Baklien K. Immunohistochemical studies of the formation and epithelial transport of immunoglobulins in normal andydiseased human intestinal mucosa. Scand J Gastroenterol 1976;11 Suppl.36;5-45.

"Söltoft J, Weeke B. Immunoglobulins in serum and jejunal biopsies in non-tropical sprue. Acta Med Scand 1969; 186:459-64.

1: Söltoft J. Immunoglobulin-containing cells in non-tropical sprue. Clin Exp Immun 1970;6:413-20.

${ }^{13}$ Savilahti E. Intestinal immunoglobulins in children with coeliac disease. Gut 1972;13:958-64.

1 Rosekrans PCM, Peña AS, Hekkens WThJM, deVries RRP, Haex AJCh. Coeliac disease. A family study in the Netherlands. In: McNicholl B, McCarthy CF, Fottrell PF, eds. Perspectives in coeliac disease. Lancaster: MTP Press, 1978;147-54.

15 Rosekrans PCM, Meijer CJLM, Cornelisse CJ, vdWal AM, Lindeman $J$. Use of morphometry and immunohistochemistry of small intestinal biopsy specimens in the diagnosis of food allergy. J Clin Pathol 1980;33: 125-30.

${ }^{16}$ Shiner M, Doniach I. Histopathologic studies in steatorrhoea. Gastroenterology 1960;38:419-40.

${ }^{17}$ Brandtzaeg P, Baklien K, Fausa O, Hoel PS. Immunohistochemical characterization of local immunoglobulin formation in ulcerative colitis. Gastroenterolog. 1974;66:1123-36.

${ }^{18}$ Otto HF. Interepitheliale Lymphozyten bei Enteropathien. Zeitschr Gastroent 1972;10:173-9.

${ }^{19}$ Lancaster-Smith M, Kumar PJ, Dawson AM. The cellular infiltrate of the jejunum in adult coeliac disease and dermatitis herpetiformis following reintroduction of dietary gluten. Gut $1975 ; 16: 683-8$.

20 Mavromichalis J, Brueton MJ, McNeish AS, Anderson CM. Evaluation of the intraepithelial lymphocyte count in the jejunum in childhood enteropathies. Gut 1976;17:600-3.

${ }^{21}$ McNicholl B, Egan-Mitchell B, Stevens F, Keane R, Baker S, McCarthy CF, Fottrell PF. Mucosal recovery in treated childhood celiac disease (gluten-sensitive enteropathy). $J$ Paediatr 1976;89:418-24.

${ }^{22}$ Holmes GT, Asquith P, Stokes PL, Cooke WT. Cellular infiltrate of jejunal biopsies in adult coeliac disease in relation with gluten withdrawal. Gut 1974;15:278-83.

${ }^{23}$ Ferguson R, Asquith P, Cooke WT. The jejunal cellular infiltrate in coeliac disease complicated by lymphoma Gut 1974;15:458-61.

${ }^{24}$ Scott H, Ek J, Baklien K, Brandtzaeg P. Immunoglobulinproducing cells in jejunal mucosa of children with coeliac disease on a gluten-free diet and after gluten challenge. Scand J Gastroenterol 1980;15:81-8.

Requests for reprints to: Dr PCM Rosekrans, Department of Gastroenterology, University Medical Centre, Rijnsburgerweg 10, 2333 AA Leiden, The Netherlands. 